\title{
FAST-GROWING WILLOW DEVELOPMENT ON ACIDIC MINING WASTES FOR RAPID GREENING PURPOSES
}

\author{
M. GUITTONNY-LARCHEVÊQUE ${ }^{1}$, A. DALLAIRE ${ }^{1} \&$ S. LORTIE $^{2}$ \\ ${ }^{1}$ Université du Québec en Abitibi-Témiscamingue, Canada. \\ ${ }^{2}$ Westwood mine, Canada.
}

\begin{abstract}
Metal mining generates large volumes of wastes, which can contain sulphide minerals that generate acid when exposed to atmospheric conditions, providing unfavourable conditions for plant establishment. In particular, mining waste rocks are piled on tens of meters, and remain devoid of vegetation, creating a desolated anthropogenic landscape. The use of adapted plants able to grow quickly on waste rocks can help increasing their aesthetical aspect. An experiment was conducted at the Westwood mine in Quebec to evaluate the establishment ability of a fast-growing willow (Salix miyabeana Sx64) on acid- generating waste rocks. The main objective was to identify substrate thickness and composition that maximized willow productivity while limiting water stress exposure and trace metal accumulation. A randomized complete block design was established in June 2014 with five treatments: (1) direct planting in waste rocks, (2) and (3) $20 \mathrm{~cm}$ or $40 \mathrm{~cm}$ moraine amended with $20 \%$ of organic matter (OM) (in volume), (4) $20 \mathrm{~cm}$ moraine at $40 \%$ of OM, and (5) $20 \mathrm{~cm}$ moraine at $20 \%$ of OM over $20 \mathrm{~cm}$ lime sludge from water treatment. Trees directly planted in waste rocks survived well (75\%) but had the lowest aerial productivity, with the lowest height and diameter growth, aerial biomass, and total leaf area, while the treatment richer in OM showed the greatest aerial biomass and total leaf area, and the thicker treatment the greatest height and diameter growth. Willow root development was restricted to cover soils the first year after planting, and foliar $\delta 13 \mathrm{C}$ values decreased in thicker soil $(40 \mathrm{~cm})$ compared to thin soil $(20 \mathrm{~cm})$. Willow accumulation factors in leaves were below one for all investigated trace metals except $\mathrm{Zn}$.
\end{abstract}

Keywords: aerial productivity, lime sludge, mine revegetation, phytostabilization, root development, soil cover, trace metals, water stress.

\section{INTRODUCTION}

Surface metal mining generates large volumes of wastes, among which mining waste rocks are piled on tens of meters along the mine life. Waste rocks are excavated rocks that surround the ore and do not contain any metal of commercial value. If they contain sulphide minerals, like pyrite, these minerals react with water and oxygen when exposed to atmospheric conditions to produce sulfuric acid. This phenomenon is called acid mine drainage (AMD), [1]. Contaminated water is collected and treated along the mine life. At mine closure, waste rock piles are restored to stop AMD. Acidification of the waste rocks increases some trace metal mobility towards plants available fraction (for example $\mathrm{Al}, \mathrm{Cr}, \mathrm{Mn}$, and $\mathrm{Zn}$ ), [2], which provides unfavourable conditions for plant establishment. Thus, waste rock piles generally remain devoid of vegetation along the mine life, creating a desolated anthropogenic landscape. However, vegetation development on waste rock piles could both stabilize them against erosion and improve their aesthetics before restoration technologies are applied. A vegetation cover could increase the mining projects acceptability by neighbouring communities, as well as improve working conditions of mine employees. 
In addition to increased metal availability, several characteristics of acidic waste rocks restrict vegetation establishment: neither organic matter nor soil organisms that create appropriate structure for water retention and provides nutrients, extreme $\mathrm{pH}$, and elevated electrical conductivity [3]. Due to waste rocks heterogeneous particle size distribution, plants may be exposed to water stress. Heterogeneous particle size distribution and lack of organic matter is not compatible with water retention. Yet, water stress is often reported as a possible explanation for plantation failure in reclaimed mine lands [4].

The use of big-sized plants able to grow quickly on waste rocks could help increasing their aesthetical aspect. Trees have been used extensively worldwide to revegetate surface mine sites, especially coal mines [5, 6]. Willow (Salix sp.) in particular is one of the first species to naturally colonize mine wastes [7] and seems well adapted to plantation on mine substrates [8]. However, willow tolerance to trace metals varies among clones and species [9] and its use on acidic mine wastes remains little studied. Among fast-growing clones producing high biomass rates, Salix miyabeana Sx64 seems tolerant to elevated acidic and saline conditions $[10,11]$ and to elevated concentrations of some trace metals $[12,13]$. To avoid metal transfer from the waste rocks towards the food web through plant consumption, trace metal phytostabilization by the used plants is desired, which means that trace metals should not be exported to aerial parts of the plants [14].

In addition to the selection of stress tolerant plants, the use of soil covers above the mine wastes is suggested to improve vegetation establishment [15]. However, if the soil volume is too low, tree survival and growth may be limited due to inadequate moisture and nutrient reserves $[3,16]$. Moreover, the inappropriate structure and toxicity of mine wastes may restrict root development to cover soils [17], which may further reduce water and nutrient uptake.

An experiment was conducted at the Westwood mine site in Quebec to evaluate the establishment ability of Salix miyabeana, clone Sx64 on acid generating waste rocks. The main objective was to identify soil cover thickness and composition (i.e. organic matter content, and presence of a lime sludge layer) that maximized willow productivity while limiting water stress exposure and trace metal accumulation. Our working hypotheses were that: (1) A thicker or OM richer soil cover will improve willow growth through decreased water and nutrient stresses; (2) A thicker soil cover will decrease trace metal accumulation in willow because a greater proportion of roots will be distant from the waste rocks; (3) The presence of a lime sludge layer with basic $\mathrm{pH}$ will decrease trace metal accumulation in willow by decreasing their availability.

\section{MATERIALS AND METHODS}

\subsection{Site description}

The experiment took place at the Westwood mine site $\left(48^{\circ} 15^{\prime} \mathrm{N}, 78^{\circ} 32^{\prime} \mathrm{W}\right)$ in Northwestern Quebec, Canada. This underground gold mine belongs to IAMGOLD Corporation and begun its activities in 2013. The site was used until 2009 by the Doyon gold mine which extracted waste rocks from an open pit. The typical forest vegetation that surrounds the mine includes Pinus banksiana Lamb., Picea mariana (Mill.) Britton, Populus tremuloides Michx., Betula papyrifera Marsh., Larix laricina (Du Roi) K. Koch, and Abies balsamea (L.) Mill. In this boreal region, the growing season typically begins in mid-May and ends in early October, with a mean temperature during the three warmest months (June, July, and August) of around $18^{\circ} \mathrm{C}-19^{\circ} \mathrm{C}$. The average annual temperature is $1{ }^{\circ} \mathrm{C}$, and the average number of frost-free days is 80 . Mean annual precipitation is around $900 \mathrm{~mm} \mathrm{[18].}$ 


\subsection{Substrates}

The experimental plantation was established over the Doyon waste rocks, which were extracted from shale bedrock. The waste rocks are acid generating which means that the acid generation potential associated to sulphide minerals is greater than the neutralization potential of other minerals constituting the waste rocks. Their mean trace metal concentrations are below Quebec's regulation thresholds for residential lands [19]. The soil used to cover the waste rocks was a sandy loam till (dystric brunisol, [20]) excavated from a borrow pit on the mine site. Humus peat soil, excavated from a local bog, was used as amendment to increase $\mathrm{OM}$ concentration of soil cover. The lime sludge used to make a layer between the waste rocks, and the cover soil was collected from the bottom of water treatment ponds. These ponds collected acidic water to which lime was mixed to precipitate metals. Table 1 presents chemical characteristics of the waste rocks fine fraction $(<2 \mathrm{~mm})$, as well as cover soil, humus peat soil, and lime sludge. Peat soil and lime sludge showed similar and greater organic matter concentrations than waste rocks and cover soil. Cover soil, peat soil and waste rocks had acidic $\mathrm{pH}$, while lime sludge had alkaline $\mathrm{pH}$ and greater electrical conductivity than the other substrates. Soils mean trace metal concentrations were below Quebec's regulation thresholds for residential lands, while lime sludge contained the greatest trace metal concentrations with $\mathrm{Co}, \mathrm{Cu}$ and $\mathrm{Mn}$ exceeding the Quebec's regulation thresholds for residential lands.

Table 1: Substrates' chemical characteristics. Mean $(\mathrm{N}=3)$.

\begin{tabular}{|c|c|c|c|c|c|c|}
\hline & & $\begin{array}{l}\text { Waste } \\
\text { rocks }\end{array}$ & $\begin{array}{l}\text { Cover } \\
\text { soil }\end{array}$ & $\begin{array}{l}\text { Lime } \\
\text { sludge }\end{array}$ & $\begin{array}{l}\text { Peat } \\
\text { soil }\end{array}$ & $\begin{array}{l}\text { Legal } \\
\text { threshold } \\
{[19]}\end{array}$ \\
\hline $\mathrm{pH}$ & & $6(0.3)$ & $6(0.4)$ & $8(0.03)$ & $5.0(0.3)$ & - \\
\hline $\mathrm{EC}^{*}$ & $\mathrm{~S} / \mathrm{m}$ & $8(3)$ & $8(0.5)$ & $22(0.1)$ & $3(0.8)$ & - \\
\hline $\mathrm{OM}^{*}$ & $\% \mathrm{DM}$ & $0.5(0.08)$ & $0.2(0.02)$ & $12(0.3)$ & $16(1.4)$ & - \\
\hline Total N & $\% \mathrm{DM}$ & $0.01(0.000)$ & $0.01(0.003)$ & $0.04(0.008)$ & $0.52(0.06)$ & - \\
\hline Total P & $\mathrm{g} / \mathrm{kg} \mathrm{DM}$ & $0.8(0.02)$ & $0.6(0.01)$ & $6(1.9)$ & $0.4(0.01)$ & - \\
\hline Total S & $\% \mathrm{DM}$ & $0.56(0.18)$ & $0.08(0.008)$ & $14.6(0.23)$ & $0.11(0.002)$ & - \\
\hline Total As & $\mathrm{mg} / \mathrm{kg} \mathrm{DM}$ & $0^{*}$ & $0^{*}$ & $6(6)$ & $0^{*}$ & 30 \\
\hline Total Cd & $\mathrm{mg} / \mathrm{kg} \mathrm{DM}$ & $0 *$ & $0 *$ & $0 *$ & $0^{*}$ & 5 \\
\hline Total Ca & $\mathrm{g} / \mathrm{kg} \mathrm{DM}$ & $5.1(0.3)$ & $3.9(0.1)$ & $276(74)$ & $6(0.2)$ & - \\
\hline Total Cr & $\mathrm{mg} / \mathrm{kg} \mathrm{DM}$ & $65(14)$ & $74(1.0)$ & $14(2.5)$ & $25(1.7)$ & 250 \\
\hline Total Co & $\mathrm{mg} / \mathrm{kg} \mathrm{DM}$ & $12(3.2)$ & $8(1.3)$ & $116(24)$ & $0^{*}$ & 50 \\
\hline Total Cu & $\mathrm{mg} / \mathrm{kg} \mathrm{DM}$ & $88(30)$ & $24(2.5)$ & $1,158(287)$ & $41(3.0)$ & 100 \\
\hline Total K & $\mathrm{g} / \mathrm{kg} \mathrm{DM}$ & $0.9(0.09)$ & $0.6(0.07)$ & $0.03(0.03)$ & $0.7(0.07)$ & - \\
\hline Total Mg & $\mathrm{g} / \mathrm{kg} \mathrm{DM}$ & $10(0.6)$ & $5.9(0.5)$ & $15(3.7)$ & $3.9(1.2)$ & - \\
\hline Total Mn & $\mathrm{g} / \mathrm{kg} \mathrm{DM}$ & $0.4(0.05)$ & $0.2(0.02)$ & $1.9(0.4)$ & $0.1(0.008)$ & 1 \\
\hline Total Mo & $\mathrm{mg} / \mathrm{kg} \mathrm{DM}$ & $0 *$ & $0 *$ & $2.3(2.3)$ & $0^{*}$ & 10 \\
\hline Total Na & $\mathrm{g} / \mathrm{kg} \mathrm{DM}$ & $0.3(0.04)$ & $0.2(0.002)$ & $0.1(0.04)$ & $0.1(0.006)$ & - \\
\hline Total Ni & $\mathrm{mg} / \mathrm{kg} \mathrm{DM}$ & $36(8)$ & $34(2.0)$ & $67(14)$ & $15(0.4)$ & 100 \\
\hline Total $\mathrm{Pb}$ & $\mathrm{mg} / \mathrm{kg} \mathrm{DM}$ & $9(2.9)$ & $0 *$ & 7 (7) & $3.7(3.7)$ & 500 \\
\hline Total Se & $\mathrm{mg} / \mathrm{kg} \mathrm{DM}$ & $0^{*}$ & $0 *$ & $0^{*}$ & $0^{*}$ & 3 \\
\hline Total Zn & $\mathrm{mg} / \mathrm{kg} \mathrm{DM}$ & $52(10)$ & $13(0.6)$ & $152(31)$ & $69(10)$ & 500 \\
\hline
\end{tabular}

*beyond detection limit; EC : electrical conductivity; OM : organic matter. 


\subsection{Plant material}

Willow stock was produced locally by a private nursery (cellule des coteaux, La Morandière, QC). It consisted of clonally propagated one-year-old whips (1-m long cuttings) from Salix miyabeana Seemen, Sx64 clone.

The field experiment was set up on waste rocks on 9 June 2014. Unrooted whips were planted to a depth of 20 to $30 \mathrm{~cm}$ in the substrates. All trees were fertilized at planting with $15 \mathrm{~g}$ ammonium nitrate (34.5-0-0) and $15 \mathrm{~g}$ triple superphosphate (0-45-0) placed into a slit made with a spade near the base of each tree $(20 \mathrm{~cm}$ from the tree and $15 \mathrm{~cm}$ deep).

\subsection{Experimental design}

A randomized, complete block design was used: 20 experimental plots $=4$ blocks (replicates) x 5 treatments (W, direct planting in waste rocks; S20-20, $20 \mathrm{~cm}$ of cover soil mixed with peat soil $(80 \%-20 \%$ ratio in fresh volume (FV)); S20-40, $20 \mathrm{~cm}$ of cover soil mixed with peat soil (60\%-40\% ratio FV); S40-20, $40 \mathrm{~cm}$ of cover soil mixed with peat soil $(80 \%-20 \%$ ratio FV); S20-LS, $20 \mathrm{~cm}$ of cover soil above a $20 \mathrm{~cm}$-layer of lime sludge) $\times 9$ whips. The sludge and soil covers were applied over the waste rocks by a mechanical shovel in late May 2014. The mix between peat soil and cover soil was done locally in each plot by a mechanical shovel, and corresponded to $87 \%$ cover soil and $13 \%$ peat soil (S20-20 and S40-20), and 74\% cover soil and $26 \%$ peat soil on a dry mass basis. Each plot covered an $4 \times 4 \mathrm{~m}$ area and all plots were aligned to construct a $80 \mathrm{~m}$-long hedge. Trees were spaced $1 \mathrm{~m} \times 1 \mathrm{~m}$ apart, and a $1 \mathrm{~m}$ buffer zone was kept free of trees at the edge of the treatment areas.

\subsection{Sampling, measurements and analyses}

\subsubsection{Substrate}

Three random samples were taken from each substrate before placement for characterization (Table 1). Plot substrates were then sampled at planting at $0-10 \mathrm{~cm}$ to characterize each treatment. Each analysed soil sample was a composite of two samples, taken in the northern and southern parts of each experimental plot $(\mathrm{N}=20,1$ sample per plot). Substrates' chemical composition was analysed on sieved $\left(2 \mathrm{~mm}\right.$ mesh), finely ground, oven-dried samples $\left(50^{\circ} \mathrm{C}\right)$ (Lakehead University Centre for Analytical Services, Thunder Bay, ON, Canada). Total N was analysed by the Dumas combustion method (LECO CNS 2,000, Mississauga, ON) and organic carbon (C) by thermogravimetric method (LECO-TGA, Mississauga, ON). Organic matter concentrations were calculated as $1.72 \times$ organic carbon $(\mathrm{C})$. Following $\mathrm{HNO} 3-\mathrm{HCl}$ digestion, sample concentrations of total $\mathrm{P}, \mathrm{K}, \mathrm{Ca}, \mathrm{Mg}, \mathrm{Na}, \mathrm{As}, \mathrm{Cd}, \mathrm{Co}, \mathrm{Cr}, \mathrm{Cu}, \mathrm{Mo}, \mathrm{Mn}, \mathrm{Ni}$, $\mathrm{Pb}$, and $\mathrm{Zn}$ were determined by inductively coupled plasma-atomic emission spectrometry (ICP-AES, Vista PRO, Varian Canada, Mississauga, ON). pH was determined in a saturated paste extract, and electrical conductivity was determined in a 1:2 water solution.

\subsubsection{Above-ground development}

Survival, stem height, and basal diameter were measured at planting and at the end of each growing season in October 2014 and 2015 for each planted tree $(9 \times 5 \times 4=180$ trees). Annual growth increment was calculated as the difference between final and initial measures. In August 2014, the second tree of each plot was harvested for aboveground biomass assessment. Trees were separated into stems and leaves. Total leaf areas were measured with a 
LI-3100 C leaf area meter (LiCor, Lincoln, NE) prior to drying. The plant parts were then oven dried at $80^{\circ} \mathrm{C}$ for $48 \mathrm{~h}$ and weighed. Specific leaf area (SLA, total leaf area / total leaf dry mass, $\mathrm{cm}^{2} \mathrm{mg}^{-1}$ ) was calculated.

\subsubsection{Water stress and foliar analyses}

In August 2014, 10 to 20 fully matured leaves were sampled on the fifth and eighth trees of each plot, then bulked by plot $(\mathrm{N}=20)$. Leaf samples were similarly taken on four control trees grown in the nursery. Sampled leaves were oven-dried $\left(50^{\circ} \mathrm{C}\right)$, ground, and analysed for the same element concentrations as for soils, using the above-mentioned analytical methods. Accumulation factors in leaves were calculated as foliar/substrate concentrations. A subsample of each foliage sample $(\mathrm{N}=20)$ was more finely ground with a Brinkmann MM2 ball grinder (Brinkmann Instruments Ltd., Mississauga, ON, Canada). Stable isotope ratios (13C/12C) were determined using a Costech ECS 4,010 Elemental combustion system (Costech Analytical Technologies Inc. Valencia, CA, USA) coupled to a continuous flow Finnigan Delta Plus Advantage IRMS (ThermoFinnigan, Bremen, Germany). The relative abundance of $13 \mathrm{C}$ in leaves was expressed in terms of carbon isotope composition $(\delta 13 \mathrm{C})$, according to the following relationship: $\delta 13 \mathrm{C}=[(\mathrm{R} 1-\mathrm{Rs}) / \mathrm{Rs}] \times 1,000$, where $\mathrm{Rl}$ and Rs refer to the $13 \mathrm{C} / 12 \mathrm{C}$ ratio in the leaf sample and in the standards, respectively.

\subsubsection{Root development}

In September 2014, at the southern side of the second tree of each plot, a $1 \times 1 \mathrm{~m}$ large and deep observation trench was dug with a mechanical shovel at a few $\mathrm{cm}$ from the stem. Then a $75 \times$ $60 \mathrm{~cm}$ grid with $5 \times 5 \mathrm{~cm}$ squares was laid against the trench to study the root distribution along the substrate profile. The presence (number of squares where a root is present / total number of squares $\times 100$ ) and numbers (number of roots in each square at: $0-5,5-10,10-15$, more than $15 \mathrm{~cm}$ ) were noted in each grid square and compiled by substrate deepness range.

\subsection{Statistical analyses}

Survival data were compared using the $\chi^{2}$ test (R software, V.3.0.3). Substrate and plant data were subjected to one-way analysis of variance (treatment effect). To meet the normal distribution criterion for ANOVA, some data were transformed by applying $\mathrm{x}^{2}, \ln$, or $1 / \mathrm{x}$ functions. If normal distribution could not be achieved, Student $t$ test was performed. All tested factors were fixed effects and the block factor was considered a random effect. When effects for a given variable were significant, Tukey tests were conducted to separate the means. Overall significance for the analyses was set at alpha $=0.05$.

\section{RESULTS}

\subsection{Willow above- and below-ground development}

Willow survival rates were significantly lower in 2014 and 2015 when planted in waste rocks (W, 75\%) compared to treatments with a soil cover (100\%). In the $\mathrm{W}$ treatment, willows also showed the lowest height (2014) and diameter (2015) annual increments, aerial biomass production, and total leaf area, while the treatment richer in OM (S20-40) showed the greatest aerial biomass and total leaf area, and the thicker treatments the greatest height (S40-20) and diameter (S40-20, S20-LS) annual increments (Fig. 1). No differences in SLA were found among treatments. 

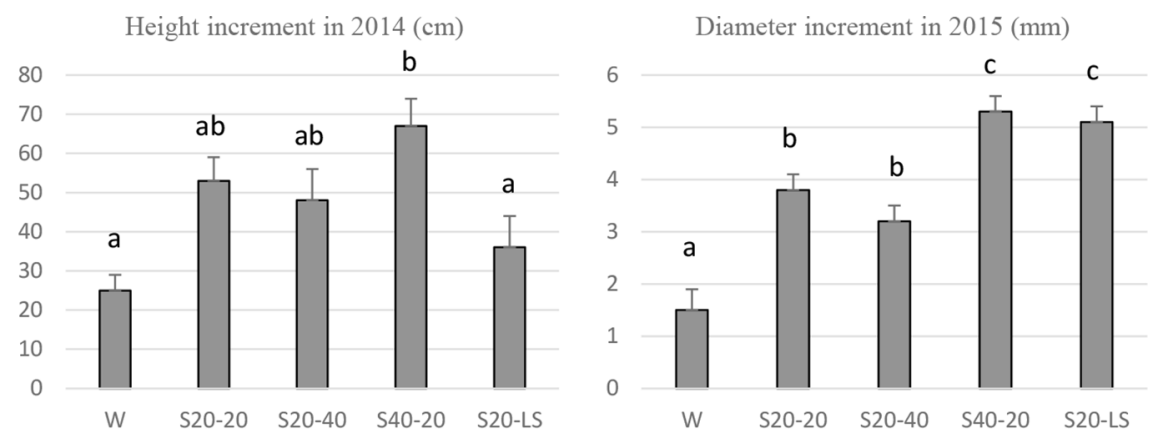

Above-ground biomass in $2014(\mathrm{~g})$
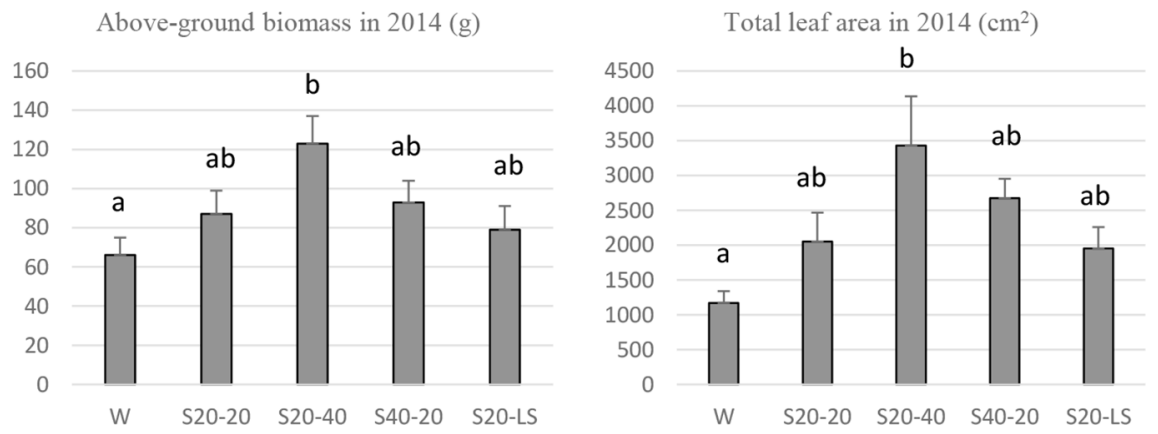

Figure 1: Willow above-ground development (height and diameter annual increments, aboveground biomass, and total leaf area) among treatments (W, direct planting in waste rocks; S20-20, $20 \mathrm{~cm}$ of cover soil mixed with $20 \%$ peat soil; S20-40, $20 \mathrm{~cm}$ of cover soil mixed with $40 \%$ peat soil; S40-20, $40 \mathrm{~cm}$ of cover soil mixed with $20 \%$ peat soil; S20-LS, $20 \mathrm{~cm}$ of cover soil above a $20 \mathrm{~cm}$-layer of lime sludge) the first (2014) and second (2015) year after planting. Means, $N=27$. Bars denote SE. Treatments denoted by the same letter do not significantly differ at $\mathrm{P}=0.05$.

The percentage of root presence relative to total grid surface was similar in all treatments $(12 \%-17 \%)$ but tended to be greater in the OM richer soil cover. However, despite observed root development when willows were planted in waste rocks alone, roots were always restricted to cover soils the first year after planting in other treatments. This resulted in differing root profiles, with on one hand root presence decreasing with depth in the waste rocks treatment, while on the other hand root presence increased with soil depth, reaching a maximum at the soil and waste rocks interface (Fig. 2).

\subsection{Substrate and foliage element analyses}

Mixing peat with cover soil decreased the mixture $\mathrm{pH}$ (5.3 to 5.6) and increased its OM concentration $(1.4 \%-5.5 \% \mathrm{DM})$ compared to the waste rocks treatment $(6.4 \%$ and $0.5 \%$, for $\mathrm{pH}$ and $\mathrm{OM}$, respectively), but differences were not significant for all soil treatments probably due to mixtures' heterogeneity. Mixing did not affect significantly mixtures' EC which remained similar to that of $\mathrm{W}$ treatment, but increased total $\mathrm{N}$, while waste rocks showed greater total $\mathrm{P}$ and $\mathrm{Zn}$ concentrations than soils (Table 2). 


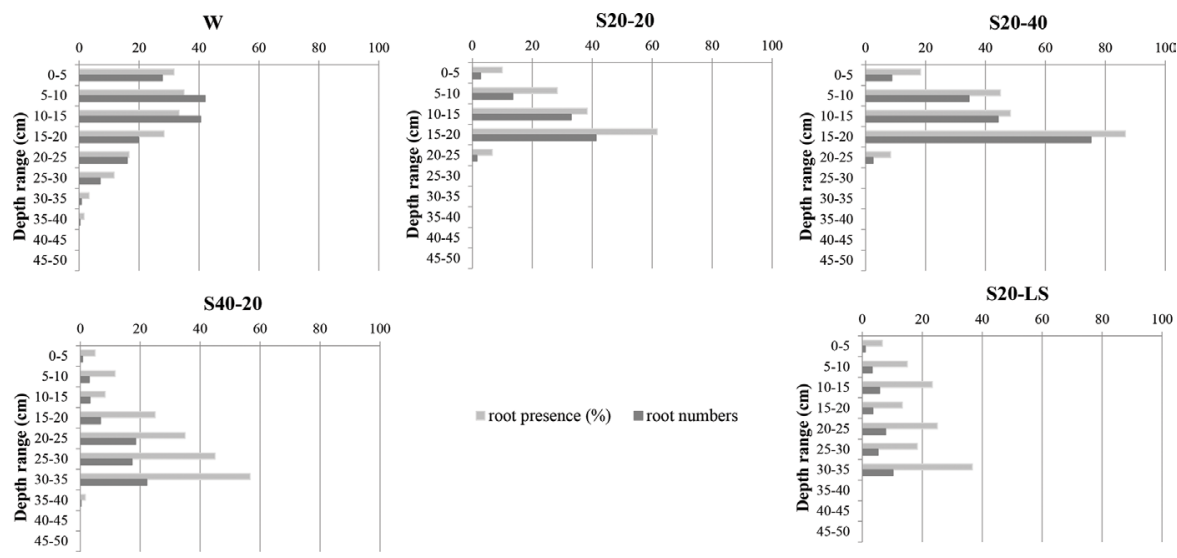

Figure 2: Willow root profiles (root presence and occurrence) along an $75 \times 60 \mathrm{~cm}$ observation trench among treatments (W, direct planting in waste rocks; S20-20, $20 \mathrm{~cm}$ of cover soil mixed with $20 \%$ peat soil; S20-40, $20 \mathrm{~cm}$ of cover soil mixed with $40 \%$ peat soil; S40-20, $40 \mathrm{~cm}$ of cover soil mixed with $20 \%$ peat soil; S20-LS, $20 \mathrm{~cm}$ of cover soil above a $20 \mathrm{~cm}$-layer of lime sludge) the first year after planting (2014). Means, $\mathrm{N}=4$.

Table 2: Total element concentrations (in dry matter) in substrates and willow foliage among treatments (W, direct planting in waste rocks; S20-20, $20 \mathrm{~cm}$ of cover soil mixed with $20 \%$ peat soil; S20-40, $20 \mathrm{~cm}$ of cover soil mixed with $40 \%$ peat soil; S40-20, $40 \mathrm{~cm}$ of cover soil mixed with $20 \%$ peat soil; S20-LS, $20 \mathrm{~cm}$ of cover soil above a $20 \mathrm{~cm}$ layer of lime sludge) the first year after planting (2014). Treatments denoted with the same lower case letter do not significantly differ at $\mathrm{P}=0.05$; Mean $(\mathrm{SE}), \mathrm{N}=4$.

\begin{tabular}{lllllll}
\hline & & \multicolumn{5}{c}{ Substrate } \\
\cline { 3 - 7 } & & $\mathrm{W}$ & $\mathrm{S} 20-20$ & $\mathrm{~S} 20-40$ & $\mathrm{~S} 40-20$ & $\mathrm{~S} 20-\mathrm{LS}$ \\
\hline $\mathrm{N}$ & $\mathrm{g} / \mathrm{kg}$ & $0.1(0.1) \mathrm{a}$ & $0.8(0.1) \mathrm{b}$ & $1.3(0.3) \mathrm{b}$ & $0.4(0.2) \mathrm{ab}$ & $0.6(0.4) \mathrm{ab}$ \\
$\mathrm{As}$ & $\mathrm{mg} / \mathrm{kg}$ & $0^{*}$ & $0^{*}$ & $0^{*}$ & $0^{*}$ & $0^{*}$ \\
$\mathrm{Cd}$ & $\mathrm{mg} / \mathrm{kg}$ & $0^{*}$ & $0^{*}$ & $0^{*}$ & $0^{*}$ & $0^{*}$ \\
$\mathrm{Ca}$ & $\mathrm{g} / \mathrm{kg}$ & $5.1(0.3) \mathrm{a}$ & $4.3(0.4) \mathrm{a}$ & $4.9(0.2) \mathrm{a}$ & $4.4(0.3) \mathrm{a}$ & $4.3(0.3) \mathrm{a}$ \\
$\mathrm{Cr}$ & $\mathrm{mg} / \mathrm{kg}$ & $65(14) \mathrm{a}$ & $66(4.3) \mathrm{a}$ & $58(3.4) \mathrm{a}$ & $74(8) \mathrm{a}$ & $72(5.6) \mathrm{a}$ \\
$\mathrm{Co}$ & $\mathrm{mg} / \mathrm{kg}$ & $12(3.2) \mathrm{a}$ & $7(1.0) \mathrm{a}$ & $5.3(0.5) \mathrm{a}$ & $6(1.0) \mathrm{a}$ & $7(0.9) \mathrm{a}$ \\
$\mathrm{Cu}$ & $\mathrm{mg} / \mathrm{kg}$ & $88(30) \mathrm{a}$ & $32(6) \mathrm{a}$ & $34(3.7) \mathrm{a}$ & $36(5.1) \mathrm{a}$ & $88(60) \mathrm{a}$ \\
$\mathrm{K}$ & $\mathrm{g} / \mathrm{kg}$ & $0.9(0.09) \mathrm{a}$ & $0.7(0.05) \mathrm{a}$ & $0.7(0.06) \mathrm{a}$ & $0.7(0.07) \mathrm{a}$ & $0.7(0.04) \mathrm{a}$ \\
$\mathrm{Mg}$ & $\mathrm{g} / \mathrm{kg}$ & $10(0.6) \mathrm{b}$ & $6(0.3) \mathrm{a}$ & $5.4(0.4) \mathrm{a}$ & $6(0.7) \mathrm{a}$ & $6(0.5) \mathrm{a}$ \\
$\mathrm{Mn}$ & $\mathrm{mg} / \mathrm{kg}$ & $400(50) \mathrm{b}$ & $200(20) \mathrm{a}$ & $200(10) \mathrm{a}$ & $200(20) \mathrm{a}$ & $200(20) \mathrm{a}$ \\
$\mathrm{Mo}$ & $\mathrm{mg} / \mathrm{kg}$ & $0^{*}$ & $0^{*}$ & $0^{*}$ & $0^{*}$ & $0^{*}$ \\
$\mathrm{Na}$ & $\mathrm{mg} / \mathrm{kg}$ & $300(40) \mathrm{b}$ & $200(10) \mathrm{a}$ & $200(10) \mathrm{ab}$ & $200(10) \mathrm{ab}$ & $200(10) \mathrm{a}$ \\
$\mathrm{Ni}$ & $\mathrm{mg} / \mathrm{kg}$ & $36(8) \mathrm{a}$ & $31(2.6) \mathrm{a}$ & $26(1.7) \mathrm{a}$ & $31(4.0) \mathrm{a}$ & $31(2.7) \mathrm{a}$ \\
$\mathrm{P}$ & $\mathrm{g} / \mathrm{kg}$ & $0.8(0.02) \mathrm{b}$ & $0.6(0.04) \mathrm{a}$ & $0.5(0.03) \mathrm{a}$ & $0.6(0.04) \mathrm{a}$ & $0.6(0.02) \mathrm{a}$ \\
$\mathrm{Pb}$ & $\mathrm{mg} / \mathrm{kg}$ & $9(2.9)$ & $0^{*}$ & $0^{*}$ & $0^{*}$ & $0^{*}$ \\
$\mathrm{Se}$ & $\mathrm{mg} / \mathrm{kg}$ & $0^{*}$ & $0^{*}$ & $0^{*}$ & $0^{*}$ & $0^{*}$ \\
$\mathrm{Zn}$ & $\mathrm{mg} / \mathrm{kg}$ & $52(10) \mathrm{b}$ & $25(3.9) \mathrm{ab}$ & $34(5.3) \mathrm{ab}$ & $18(1.6) \mathrm{a}$ & $22(7) \mathrm{a}$ \\
\hline
\end{tabular}


Table 2: (Continued)

\begin{tabular}{llllllll}
\hline & & \multicolumn{6}{c}{ Foliage } \\
\cline { 3 - 7 } & & $\mathrm{W}$ & $\mathrm{S} 20-20$ & $\mathrm{~S} 20-40$ & $\mathrm{~S} 40-20$ & $\mathrm{~S} 20-\mathrm{LS}$ & Control \\
\hline $\mathrm{N}$ & $\%$ & $1.5(0.2) \mathrm{a}$ & $3.1(0.1) \mathrm{cb}$ & $2.8(0.1) \mathrm{bc}$ & $3.4(0.1) \mathrm{d}$ & $3.0(0.1) \mathrm{bc}$ & $2(0.3) \mathrm{ab}$ \\
$\mathrm{As}$ & $\mathrm{mg} / \mathrm{kg}$ & $0^{*}$ & $0^{*}$ & $0^{*}$ & $0^{*}$ & $0^{*}$ & $0^{*}$ \\
$\mathrm{Cd}$ & $\mathrm{mg} / \mathrm{kg}$ & $0.7(0.5) \mathrm{a}$ & $2.1(0.7) \mathrm{a}$ & $6.1(1.0) \mathrm{b}$ & $3.9(1.4) \mathrm{ab}$ & $0(0)^{*} \mathrm{a}$ & $0(0)^{*} \mathrm{a}$ \\
$\mathrm{Ca}$ & $\mathrm{g} / \mathrm{kg}$ & $25.2(1.5) \mathrm{b}$ & $13.9(0.7) \mathrm{a}$ & $17.8(0.6) \mathrm{a}$ & $17.2(1.9) \mathrm{a}$ & $18.2(0.8) \mathrm{a}$ & $15(1.4) \mathrm{a}$ \\
$\mathrm{Cr}$ & $\mathrm{mg} / \mathrm{kg}$ & $5.1(5.1)$ & $0^{*}$ & $0^{*}$ & $0^{*}$ & $0^{*}$ & $0 *$ \\
$\mathrm{Co}$ & $\mathrm{mg} / \mathrm{kg}$ & $1.0(0.6) \mathrm{ab}$ & $1.1(0.4) \mathrm{ab}$ & $0.3(0.3) \mathrm{a}$ & $0.5(0.5) \mathrm{a}$ & $1.9(0.2) \mathrm{b}$ & $3.5(1.2) \mathrm{b}$ \\
$\mathrm{Cu}$ & $\mathrm{mg} / \mathrm{kg}$ & $6.4(0.6) \mathrm{ab}$ & $8.6(0.4) \mathrm{bc}$ & $7.8(0.4) \mathrm{bc}$ & $9.1(0.6) \mathrm{c}$ & $8.7(0.4) \mathrm{bc}$ & $4.3(0.7) \mathrm{a}$ \\
$\mathrm{K}$ & $\mathrm{g} / \mathrm{kg}$ & $12(0.8) \mathrm{a}$ & $19(1.3) \mathrm{b}$ & $15(0.4) \mathrm{ab}$ & $17(2.2) \mathrm{ab}$ & $13(1.4) \mathrm{a}$ & $15(0.9) \mathrm{ab}$ \\
$\mathrm{Mg}$ & $\mathrm{g} / \mathrm{kg}$ & $2.7(0.3) \mathrm{a}$ & $3.5(0.4) \mathrm{ab}$ & $3.0(0.2) \mathrm{a}$ & $3.2(0.2) \mathrm{a}$ & $5.6(0.4) \mathrm{b}$ & $3.4(0.7) \mathrm{a}$ \\
$\mathrm{Mn}$ & $\mathrm{mg} / \mathrm{kg}$ & $280(36) \mathrm{b}$ & $161(11) \mathrm{a}$ & $148(18) \mathrm{a}$ & $175(26) \mathrm{ab}$ & $123(6) \mathrm{a}$ & $111(20) \mathrm{a}$ \\
$\mathrm{Mo}$ & $\mathrm{mg} / \mathrm{kg}$ & $0^{*}$ & $0^{*}$ & $0^{*}$ & $0^{*}$ & $0^{*}$ & $0 *$ \\
$\mathrm{Na}$ & $\mathrm{mg} / \mathrm{kg}$ & $52(6) \mathrm{b}$ & $32(5) \mathrm{b}$ & $43(5) \mathrm{b}$ & $49(8) \mathrm{b}$ & $45(4) \mathrm{b}$ & $5(3) \mathrm{a}$ \\
$\mathrm{Ni}$ & $\mathrm{mg} / \mathrm{kg}$ & $2.4(2.4) \mathrm{a}$ & $10.3(2.5) \mathrm{b}$ & $0(0)^{*} \mathrm{a}$ & $4.9(2.9) \mathrm{ab}$ & $0(0) * \mathrm{a}$ & $11(2.2) \mathrm{b}$ \\
$\mathrm{P}$ & $\mathrm{g} / \mathrm{kg}$ & $2.1(0.2) \mathrm{a}$ & $2.1(0.4) \mathrm{a}$ & $1.6(0.03) \mathrm{a}$ & $2.0(0.1) \mathrm{a}$ & $2.2(0.2) \mathrm{a}$ & $5.4(0.2) \mathrm{b}$ \\
$\mathrm{Pb}$ & $\mathrm{mg} / \mathrm{kg}$ & $0^{*}$ & $0^{*}$ & $0^{*}$ & $0^{*}$ & $0^{*}$ & $0 *$ \\
$\mathrm{Se}$ & $\mathrm{mg} / \mathrm{kg}$ & $0^{*}$ & $0^{*}$ & $0^{*}$ & $0^{*}$ & $0^{*}$ & $0 *$ \\
$\mathrm{Zn}$ & $\mathrm{mg} / \mathrm{kg}$ & $145(25) \mathrm{ab}$ & $106(13) \mathrm{ab}$ & $244(36) \mathrm{b}$ & $257(98) \mathrm{b}$ & $102(8) \mathrm{ab}$ & $76(5) \mathrm{a}$ \\
\hline
\end{tabular}

* beyond detection limit; EC : electrical conductivity; OM : organic matter.

Willows had the lowest foliage $\mathrm{N}$ concentration in $\mathrm{W}$ treatment, but this concentration did not differ than the nursery grown control, while in the OM richer treatment (S20-40), foliage had the greatest $\mathrm{N}$ concentration, but also the greatest $\mathrm{Cd}$ concentrations compared to other treatments (Table 2). W treatment had greater Mn concentrations in foliage compared to others treatments. It was also characterized by the presence of $\mathrm{Cr}$ in foliage while this element was undetectable in the foliage of willows grown in all others treatments. Despite greater trace metal concentrations in lime sludge than in soils and waste rocks (Table 1), willows grown in the S20-LS treatment did not accumulate any metal compared to other treatments (Table 2). Willow accumulation factors in foliage were below one for all investigated trace metals, except $\mathrm{Zn}$ (from 3 in $\mathrm{W}$ to 14 in S40-20 treatments). This metal concentration significantly increased in the foliage of S40-20 and S20-40 treatments compared to the nursery grown control. Finally, even if Cd concentrations were below detection limits in used substrates, this element was present in the foliage of willows grown at the mine site, especially in S20-40 treatment. Willows grown at the mine site had also greater $\mathrm{Na}$ (x 6 to 10) and lower $\mathrm{P}$ (x 1/2) concentrations in foliage whatever the treatment compared to the nursery control.

Carbon isotopic ratio in willow foliage was the lowest in W treatment $(-29.6)$ and the greatest in thin soil cover with low OM (S20-20, -27.1). The thicker soil cover (S40-20) allowed significantly lower ratio (-28.3) than S20-20, but greater than W.

\section{DISCUSSION}

S. miyabeana was able to survive and grow when directly planted in the waste rocks but had reduced foliar N and aerial growth. Since low organic matter substrates like mine wastes have 
decreased nutrient retention [3], $\mathrm{N}$ brought by placed fertilization at planting may have been lost. Contrary to what was expected, willows planted on waste rocks did not experience water stress (lowest $\mathrm{C}$ isotopic ratio, [21]) probably due to decreased aerial biomass and total leaf area that reduced transpiring surface [22]. Moreover, the electrical conductivity of waste rocks appeared similar to that of the soil covers. Finally, willows were able to insure their water supply by growing roots in the waste rocks alone treatment. These results confirm that willows are well adapted pioneers to colonize mine wastes, even if limited growth may reduce their greening effect.

According to our first hypothesis, the use of soil covers improved willow greening effect through increased survival and aerial development; the thicker the cover soil, the greater the foliar $\mathrm{N}$ concentration, height and diameter growth, while the OM richer the cover soil, the greater the aerial biomass and total leaf area. Increased above-ground biomass associated to the OM richer cover could have resulted in an N dilution effect in leaves. Since root development of willows was impeded by waste rocks under the cover soils the first year after planting, the use of thicker and richer soils probably allowed root access to greater resources $[15,3]$, especially $\mathrm{N}$, that may have improved aerial growth. Similar results were found in other mining contexts, where thicker soil covers increased $\mathrm{N}$ nutrition of trees as well as their aerial development [16]. Since foliar $\mathrm{C}$ isotopic ratio increased in soil cover treatments compared to waste rocks, increased aerial development concomitant to restricted root growth in covers may have exposed willows to water stress. The use of a thicker soil cover reduced this potential water stress exposure (lower $\mathrm{C}$ isotopic ratio) compared to other cover treatments.

S. miyabeana showed promising abilities for waste rocks' phytostabilization at the short term since its accumulation factors in leaves were lower than one for all trace metals but $\mathrm{Zn}$. Moreover, unlike in other [23], trace metal presence did not seem to reduce root growth or to limit water absorption by roots. However, metal accumulation in the willows should be followed at the longer term since the acid generating properties of the waste rocks can persist over decades. In our study, willows planted in the waste rocks showed greater concentrations of $\mathrm{Cr}$ and $\mathrm{Mn}$ in their foliage compared to other treatments, and both these metals availability increase at low $\mathrm{pH}[2,23]$.

Regarding Zn, S. miyabeana was shown in another study to have phytoextraction potential for this metal, as well as for $\mathrm{Cd}$ [13]. The willow accumulation of $\mathrm{Zn}$ in leaves was the greatest in thicker and OM richer soils, reaching concentrations that may be phytotoxic (100$400 \mathrm{ppm})$, [24], but with accumulation concentrations far lower than those required for phytoextraction [14]. Regarding Cd, despite concentrations below detection limits in the used substrates, this metal was present in the willow foliage, confirming this metal mobility towards $S$. miyabeana. In both cases, the acidification of the soil due to mixing with peat could have participated in increasing $\mathrm{Zn}$ and Cd availability to roots [23].

Contrary to our second hypothesis, the use of a thicker soil cover did not reduce trace metal accumulation compared to a thinner soil cover. Willow roots grew until they met the underlying waste rocks whatever the cover thickness. Metal accumulation factors were similar in the treatment with the lime sludge and the other treatments, demonstrating no barrier effect of the lime sludge against trace metal accumulation by willows despite its alkaline $\mathrm{pH}$ [2].

In conclusion, S. miyabeana Sx64 was well adapted to planting on acidic waste rocks at the short-term. We recommend the use of thicker (and to a lesser extent richer) soil covers to improve greening effect through increased resources (N, water) stocks, but long-term following appears essential. First, thicker and richer treatments showed the greatest $\mathrm{Zn}$ accumulation 
in foliage. Second, if the restriction of root penetration into waste rocks underlying soil covers persists, it could create mechanical instability and resource shortage, especially water, along with willow size increase.

\section{REFERENCES}

[1] Aubertin, M., Bussière, B. \& Bernier, L., Environnement et gestion des rejets miniers, Presses Internationales Polytechnique, 2002.

[2] Markert, B., Kayser, G., Korhammer, S. \& Oehlmann, J., Distribution and effects of trace substances in soils, plants and animals. Trace Elements: Their Distribution and Effects in the Environment, ed. J.P. Vernet, 4th edn., Elsevier: Amsterdam, pp. 3-32, 2000. http://dx.doi.org/10.1016/S0927-5215(00)80004-1

[3] Tordoff, G.M., Baker, A.J.M. \& Willis, A.J., Current approaches to the revegetation and reclamation of metalliferous mine wastes. Chemosphere, 41, pp. 219-228, 2000. http://dx.doi.org/10.1016/S0045-6535(99)00414-2

[4] Moffat, A.J., Minimum soil depths for the establishment of woodland on disturbed ground. Arboricultural Journal, 19, pp. 19-27, 1995. http://dx.doi.org/10.1080/03071375.1995.9756445

[5] Emerson, P., Skousen, J. \& Ziemkiewicz, P., Survival and growth of hardwoods in brown versus gray sandstone on a surface mine in West Virginia. Journal of Environmental Quality, 38, pp. 1821-1829, 2009. http://dx.doi.org/10.2134/jeq2008.0479

[6] Maiti, S.K., Bioreclamation of coalmine overburden dumps-with special emphasis on micronutrients and heavy metals accumulation in tree species. Environmental Monitoring and Assessment, 125(1-3), pp. 111-122, 2007. http://dx.doi.org/10.1007/s10661-006-9244-3

[7] Gibson, D.J., The natural revegetation of lead/zinc mine spoil in northeastern Oklahoma. The Southwestern Naturalist, 27(4), pp. 425-436, 1982. http://dx.doi.org/10.2307/3670717

[8] Mosseler, A., Major, J.E. \& Labrecque, M., Growth and survival of seven native willow species on highly disturbed coal mine sites in eastern Canada. Canadian Journal of Forest Research, 44, pp. 340-349, 2014. http://dx.doi.org/10.1139/cjfr-2013-0447

[9] Boyter, M.J, Brummer, J.E. \& Leininger, W.C., Growth and metal accumulation of geyer and mountain willow grown in topsoil versus amended mine tailings. Water Air Soil Pollution, 198, pp. 17-29, 2009. http://dx.doi.org/10.1007/s11270-008-9822-9

[10] Mirck, J. \& Volk, T.A., Response of three shrub willow varieties (Salix spp.) to storm water treatments with different concentrations of salts. Bioresource Technology, 101, pp. 3484-3492, 2010. http://dx.doi.org/10.1016/j.biortech.2009.12.128

[11] Hangs, R.D., Schoenau, J.J., Van Rees, K.C.J. \& Steppuhn, H., Examining the salt tolerance of willow (Salix spp.) bioenergy species for use on salt-affected agricultural lands. Canadian Journal of Plant Sciences, 91, pp. 509-517, 2011. http://dx.doi.org/10.4141/cjps10135

[12] Harada, E., Hokura, A., Nakai, I., Terada, Y., Baba, K., Yazaki, K., Shiono, M., Mizuno, N. \& Mizuno, T., Assessment of willow (Salix sp.) as a woody heavy metal accumulator: field survey and in vivo X-ray analyses. Metallomics, 3, pp. 1340-1346, 2011. http://dx.doi.org/10.1039/c1mt00102g 
[13] Zhivotosky, O.P., Kuzovkina, J.A., Schulthess, C.P., Morris, T., Pettinelli, D. \& Ge, M., Hydroponic screening of willows (Salix L.) for lead tolerance and accumulation. International Journal Phytoremediation, 13, pp. 75-94, 2011. http://dx.doi.org/10.1080/15226511003671361

[14] Mahar, A., Wang, P., Ali, A., Kumar Awasthi, M., Hussain Lahori, A., Wang, Q., Li, R. \& Zhang, Z., Challenges and opportunities in the phytoremediation of heavy metals contaminated soils: a review. Ecotoxicology and Environmental Safety, 126, pp. 111-121, 2016. http://dx.doi.org/10.1016/j.ecoenv.2015.12.023

[15] Cooke, J.A. \& Johnson, M.S., Ecological restoration of land with particular reference to the mining of metals and industrial minerals: a review of theory and practice. Environment Reviews, 10, pp. 41-71, 2002. http://dx.doi.org/10.1139/a01-014

[16] Larchevêque, M., Desrochers, A., Bussière, B. \& Cimon, D., Plantation of trees in soil layers for the reclamation of non-acid generating wastes of a boreal gold mine. Ecoscience, 21(3-4), pp. 217-231, 2014.

http://dx.doi.org/10.2980/21-(3-4)-3697

[17] Larchevêque, M., Desrochers, A., Bussière, B., Cartier, H. \& David, J.-S., Revegetation of non acid-generating, thickened tailings with boreal trees: a greenhouse study. Journal of Environmental Quality, 42, pp. 351-360, 2013.

http://dx.doi.org/10.2134/jeq2012.0111

[18] Government of Canada, National climate archives, available at http://climate.weather. gc.ca/

[19] Government of Quebec. Annexe I: Règlement sur la protection et la réhabilitation des terrains, LQE Chapitre Q2 r.37, available at www2.publicationsduquebec.gouv.qc.ca/ dynamicSearch/telecharge.php?type=3\&file=/Q_2/Q2R37.htm

[20] Agriculture and Agri-Food Canada, The Canadian system of soil classification, 3rd ed., available at http://sis.agr.gc.ca/cansis/taxa/cssc3/index.html

[21] Farquhar, G.D., Ehleringer, J.R. \& Hubick, K.T., Carbon isotope discrimination and photosynthesis. Annual Review Plant Physiology Plant Molecular Biology, 40, pp. 503-537, 1989.

http://dx.doi.org/10.1146/annurev.pp.40.060189.002443

[22] Pallardy, S.G., Physiology of Woody Plants, 3rd edn., Academic Press: Burlington, MA, 2008.

[23] Prasad, M.N. \& Strzalka, K., Physiology and biochemistry of metal toxicity and tolerance in plants. Physiological Responses of Vascular Plants to Heavy Metals, Kluwer Academic Publisher, pp. 149-171, 2002. http://dx.doi.org/10.1007/978-94-017-2660-3

[24] Kabata-Pendias, A. \& Pendias, H., Trace Elements in Soil and Plants, 3rd edn., CRC Press: Boca Raton, FL, 2001. 